\title{
Effects of Sorusangzi Massage on Stress, Fatigue, and Depression in Middle-aged Working Women
}

Ji On Park ${ }^{*}$, Yun Hee Son, Eun-Hwa Ju

Department of Complementary and Alternative Medicine, Chosun University, Gwangju, Korea

\author{
*Corresponding author: Ji On Park, \\ Department of Complementary and \\ Alternative Medicine, Chosun University, 309 \\ Pilmun-daero, Dong-gu, Gwangju 61452, \\ Korea \\ Tel.: +82629700136 \\ Fax: +82 629700492 \\ Email: nouvelle1236@hanmail.net
}

Received October 21, 2016

Revised January 20, 2017

Accepted February 1, 2017

Published March 30, 2017

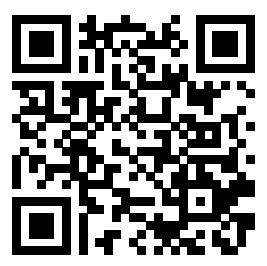

\begin{abstract}
Purpose: This study investigates the effects of Sorusangzi massage on stress, chronic fatigue, and depression in middle-aged working women. Moreover, it confirms the applicability of Sorusangzi massage as an interventional alternative therapy for a healthy aging society. Methods: In this study, 40 middle-aged women working as insurance planners were divided into experimental and control groups, each comprising 20 participants. In the experimental group, participants' degrees of stress, fatigue, depression, blood pressure, and pulse rate were measured after performing Sorusangzi massage twice per week for six weeks. Results: After Sorusangzi massage was performed, the experimental group showed less stress and fatigue with significant differences: the average score of stress was 4.1 points in the experimental group and 7.2 points in the control group, and the average score of fatigue was 14.9 points in the experimental group and 19.5 points in the control group. With regard to changes in blood pressure and pulse rate, the experimental group also exhibited significantly decreased blood pressure: systolic blood pressure was $109.0 \mathrm{mmHg}$ in the experimental group and $124.7 \mathrm{mmHg}$ in the control group, and diastolic blood pressure was $64.4 \mathrm{mmHg}$ in the experimental group and 81.4 $\mathrm{mmHg}$ in the control group. Pulse rate was 75.8 beats/min in the control group and 64.7 beats/min in the experimental group, showing significantly decreased pulse rate in the experimental group. Conclusion: The results of this study indicate positive effects of Sorusangzi massage on stress and fatigue relief. Furthermore, it reveals that Sorusangzi massage can ultimately improve the psychological conditions and quality of life of middle-aged working women. This study concludes that Sorusangzi massage may serve as an interventional alternative therapy for a healthy aging society.
\end{abstract}

Keywords: Sorusangzi massage, Stress, Fatigue, Depression, Middle-aged women

\section{Introduction}

최근 의학의 발달과 경제수준의 향상으로 여성의 건강과 삶의 질이 사회적인 측면에서 관심사로 대두되고 있으며, 저출산 및 고 령화 사회로 변하면서 노동력의 부족 문제에 대한 대안으로 기혼 여성들의 경제활동 참여가 증가하고 있다. 통계청 자료에 의하면 2015년 65세 이상 인구는 전체인구의 $13.1 \%$ 이며 2060년에는 40\% 대까지 늘어날 것으로 전망하고 있다. 또한, 현재 한국 인구의 중위 연령은 40.8세로 유럽의 41.4세보다 0.6\% 낮은 수준이나 2060년 에는 57.9 세로 유럽 45.8 세보다 12.1 세 높아질 전망이며 중년기에
해당하는 준고령(50-60세) 인구는 약 10년 후인 2024년까지 증가 할 전망이다(KOSIS, 2015). 이처럼 짧은 기간에 이루어진 고령화 사회에 대한 준비를 하기 위해 최근 여성의 재취업을 위한 정책지 원이 활발해지면서, 40 대 여성의 경제활동 참여율은 1980 년 $57.0 \%$ 에서 2007년 63.8\%로 큰 폭으로 증가하였으며, 중년여성의 노동시 장 참여율은 30 대를 비롯하여 40-60대까지 전 연령층에서 확대되 고 있다(Kim, 2010).

여성을 대상으로 진행한 선행 연구들은 주로 우울, 불안, 피로, 폐경에 초점을 맞추고 있으나(Park \& Lee, 2002), 우울증, 불안장 애와 같은 정신건강 문제를 다룬 우리나라의 역학조사 결과가 많지 
않고, 동일한 기준을 사용하더라도 대상자의 연령, 평가도구의 종 류, 측정방법에 따라서 유병율의 차이를 보이고 있다(Kwon et al., 2016). 이들의 연구에 의하면 여성의 피로와 우울, 스트레스는 개 인과 가족에게 까지 영향을 미쳐 삶의 질을 낮추는 중요한 문제가 되고 있다.

중년기 여성은 어느 시기보다도 내·외적으로 다가오는 변화에 적응하여야 하는 부담과 폐경 및 노화현상과 같은 신체적 변화를 겪을 뿐만 아니라, 출산과 육아가 끝난 40 세 이후는 재취업을 하는 경향이 있어 직장과 가정이라는 이중 노동 및 심각한 역할 갈등을 겪게 된다(Kim et al., 1994). 이러한 스트레스에 적절히 대처하지 못하면 건강에 심각한 영향을 끼치고, 나아가 가족 구성원들에게도 막대한 지장을 초래할 수 있기 때문에 개인적 및 사회적으로 스트 레스나 피로에 대처하는 것이 중요하다. Shim (2006)은 스트레스 로 인한 생리적인 변화로 중추신경계의 활동이 증가하고 혈압이 상 승하며 심장박동과 호흡이 빨라지게 되며 근육 내 혈관을 확장시키 고 골격근을 수축시켜 전신의 근육이 긴장하게 된다고 하였다.

최근 건강유지와 건강증진에 관한 연구들이 많이 보고되고 있으 며(Heo et al., 2013; Park et al., 2013; Park \& Lee, 2002), 건강 유지와 증진뿐만 아니라 질병치료를 목적으로 대체의학 분야에 대 한 의료인과 일반인의 관심이 증가하고 있어, 다양한 대체요법이 소개되고 있다(Cho \& Cho, 2007).

대체요법은 신체 증상만을 치료하는 것이 아니라 질병을 예방하 고 자연 치유력을 이용하여 신체를 건강한 상태로 회복시키는 방법 이다. 특히 마사지는 인간 활동의 기원과 함께 자연 발생적인 습관 으로 사용되어 왔으며, 현대의학에서는 환자의 치료적 마사지로 연 구되어 수세기 동안 그 발전을 거듭해 오고 있다(Han et al., 2013). Ernst (2003)는 마사지요법이 노폐물을 제거하고, 영양소 및 산소 공급을 원활하게 함으로써 신진대사를 활발하게 할 뿐만 아니라, 손을 이용하여 인체의 연조직을 자극하여 열을 발생시킴으로써 혈 관이 확장되어 혈액순환과 림프순환을 촉진시켜 근육의 긴장으로 인해 나타나는 긴장성 두통 등에 효과적이라고 하였다.

근육의 긴장으로 인한 긴장성 통증은 다양한 강도, 빈도 및 지속시 간을 가지고 대개 양측 측두부, 후두부, 목, 어깨 부위에 둔통이나 조 이는 느낌, 압박감 등으로 나타나며 전체 통증의 약 80-90\%를 차지하 여 일반 임상환자에서 흔히 볼 수 있다. 이는 어떤 질환의 증상이거나, 어떤 유해한 물질에 의한 신체적 반응으로 통증을 일으키는 원인은 다양하며 통증의 양상도 다르게 나타난다(Haber et al., 1985).

마사지의 기본 수기로는 경찰법(勁擦去), 마찰법(摩擦去), 유날 법(揉捺法), 지압법(指壓法), 진동법(振動法), 소루(疏漏)기법 등으 로 여러 가지 다른 치료적 개념의 응용 기법들이 시행되고 있다 (Park \& Suh, 1995). Han \& Kang (2014)이 개발한 소루(疏漏)마 사지요법은 찰법(擦去)을 통해 에너지를 발생시켜 에너지 순환로의 장애를 제거하고, 기를 순환시킴으로써 근육과 심장의 혈액순환 및 림프순환을 원활하게 하여 신체 조직 특히 근육이나 신경계에 새로
운 활력을 주고 노폐물 제거와 영양소 및 산소 공급을 원활하게 하 는 수기적 요법을 말한다(Han et al., 2013).

본 연구에서는 소루마사지요법의 하나로 손과 팔을 위주로 하는 마사지 방법인 소루상지마사지가 중년 직장여성들이 스트레스, 만 성피로, 우울에 대처하는데 도움이 될 수 있는지를 연구하여 건강 한 고령사회를 맞이하는데 중재적 대체요법으로의 활용 가능성을 확인하고자 하였다.

\section{Methods}

\section{1. 연구 대상 및 자료 수집}

본 연구는 보험설계사로 활동하고 있는 중년 직장여성 40 명을 대상으로 하여 설문조사와 혈압 및 맥박을 측정하였다. 각 20명씩 실험군과 대조군으로 나누었고, 실험군 20 명에 대하여 설문조사를 하였으며, 6 주에 걸쳐 주 2 회 $20 \mathrm{~min}$ 동안 소루상지마사지를 시행 한 후 혈압 및 맥박을 측정하였다. 실험군 20 명 중 4 명이 탈퇴하여 최종 16 명을 대상으로 자료분석을 하였다. 대조군 20 명에 대해서 는 직장에 방문하여 조용한 곳에서 $20 \mathrm{~min}$ 정도 안정을 취하게 한 다음 설문지 작성 후 혈압과 맥박을 측정하였다.

\section{2. 사전 동질성 검사}

연구 변인인 피험자들의 스트레스, 피로, 우울, 혈압 및 맥박수를 그룹별로 실험 처치 전 사전 측정하여 그룹 간 동질성을 검증하였다.

\section{3. 연구 방법}

1) 스트레스

본 연구에서는 스트레스 측정 도구 총 30 문항을 사용하였다. 영 역별 스트레스 점수는 0-3점까지 4점 척도로 범위는 0-45점이다. 스트레스 수준의 구분은 0-5점은 평균치 이하로 특별히 문제가 없 는 정도, 6-12점은 평균수준 평균보다 조금 높으므로 약간의 주의 가 필요한 경우, 20 점 이상은 경고수준으로 위험수위이므로 상당한 주의 또는 의사와 상의가 필요한 정도로 분류하며, 점수가 높을수 록 스트레스가 높음을 의미한다. 본 연구에서의 총 스트레스 도구 신뢰도는 Cronbach's alpha $=0.7831$ 이었다.

\section{2) 피로도}

본 연구에서는 총 22 문항의 구조화된 질문지를 사용하였다. 각 문 항은 1-4점 척도로 표시하였고, 점수가 높을수록 피로가 높음을 의 미한다. 본 연구에서의 신뢰도는 Cronbach's alpha=0.9670이었다.

\section{3) 우울도}

우울의 측정 도구는 Beck의 우울척도(Beck depression inventory, BDI)의 한국어판 BDI (Lee \& Song, 1991)를 활용하여 
측정하였다. $\mathrm{BDI}$ 는 지난 2 주간 우울증상의 인지적, 정서적, 신체적 증상 영역을 포함하는 21 개 문항으로 구성되며, 총점은 0-63점이 다. 점수가 낮을수록 우울 정도가 낮음을 의미한다. 본 연구에서 신 뢰도는 Cronbach's alpha $=0.7419$ 이었다.

\section{4) 혈압 및 맥박 측정}

혈압의 측정은 앉은 자세에서 팔을 심장 높이로 하고 우측 상완 에서 수은 혈압계와 청진기를 이용하여 상완동맥 2-3 cm 위에 커 프를 한 손가락 들어갈 정도로 감고 압력을 올려 요골동맥에서 맥 박이 촉지되지 않는 점을 확인한 후 압력을 내리고 다시 압력을 올 리기 전에 30-60 s 정도 기다렸다가 판형청진기를 상완동맥 위 에 놓은 후 압력을 올리되 촉지점보다 20-30 mmHg 더 올려 2-4 $\mathrm{mmHg} / \mathrm{s}$ 속도로 내리면서 수은주의 눈금을 눈높이에서 읽었다. 측정오차를 줄이기 위해 혈압의 수치는 두 번을 반복한 평균값으로 하였다. 맥박은 대상자를 편안한 자세로 손바닥을 위로 향하게 한 후 요골맥박에서 $30 \mathrm{~s}$ 간격으로 2 번 측정하여 기록하였다.

\section{4. 소루상지마사지 시행}

소루상지마사지요법은 실험 6 주간 주 2회 양쪽 상지(손, 팔)에 20 $\min$ 동안 시행하였다. 실험 기간 중 평소에 복용하던 약물 또는 물 리 치료 등의 치료를 중단하기로 약속하고 실시하였다. 한 사람의 시술 시간은 약 $20 \mathrm{~min}$ 정도 소요되었고, 따뜻하고 조용하며 편안 한 상태에서 외부 자극이 거의 없는 실내에서 시행하였다. 실험군 에 대한 소루상지마사지요법에 대한 구체적인 방법은 다음과 같다.

1) 엎드린 상태에서 왼쪽 팔부터 손바닥의 구심성 경로를 따라 에너지가 들어갈 수 있게 원을 그리며 150회를 회전 시행하였다.

2) 주관절 중심으로 원을 그리며 $2 \mathrm{~min}$ 동안 마사지를 시행하였다.

3) 관절 중심으로 원을 그리며 $2 \mathrm{~min}$ 동안 마사지를 시행하였다.

4) 주관절 외측은 원을 길게 그리며 시술자 자신의 다섯째 손가락 방향으로, 내측은 시술자 자신의 엄지 손가락 방향으로 $2 \mathrm{~min}$ 동안 마사지를 시행하였다.

5) 요골근에 원을 그리며 $2 \mathrm{~min}$ 동안 마사지를 시행하였다.

6) 상지 전체를 전면과 후면을 나누어 원을 길게 그리며 쓸어주기를 $2 \mathrm{~min}$ 동안 시행하였다.

7) 다시 따뜻한 열에너지가 손바닥 중심의 구심성 경로를 따라 에너지

Table 1. General specifications about the survey participants

\begin{tabular}{|c|c|c|c|}
\hline & Division & Frequency $(\mathrm{N})$ & Percent (\%) \\
\hline \multirow{2}{*}{ Age } & $40 \mathrm{~s}$ & 18 & 50.0 \\
\hline & $50 \mathrm{~s}$ & 18 & 50.0 \\
\hline \multirow{2}{*}{ Marriage } & Married & 35 & 97.2 \\
\hline & Bereaved & 1 & 2.8 \\
\hline \multirow{2}{*}{ Spouse } & With spouse & 32 & 88.9 \\
\hline & Without spouse & 4 & 11.1 \\
\hline \multirow{4}{*}{ Family } & Alone & 2 & 5.6 \\
\hline & Couple only & 1 & 2.8 \\
\hline & With children & 31 & 86.1 \\
\hline & Other cases & 2 & 5.6 \\
\hline \multirow{4}{*}{ Religion } & Christianity & 17 & 47.2 \\
\hline & Buddhism & 7 & 19.4 \\
\hline & Catholicism & 3 & 8.3 \\
\hline & None & 9 & 25.0 \\
\hline \multirow{3}{*}{ Schooling } & Middle school & 2 & 5.6 \\
\hline & High school & 23 & 63.9 \\
\hline & College or higher & 11 & 30.6 \\
\hline \multirow{2}{*}{ Monthly income } & Over $2,500,000$ won & 29 & 80.6 \\
\hline & Below $1,500,000$ won & 7 & 19.4 \\
\hline \multirow{5}{*}{ Medical treatment } & Medicinal therapy & 4 & 11.1 \\
\hline & Physical therapy & 5 & 13.9 \\
\hline & Oriental medicine & 3 & 8.3 \\
\hline & Auto-therapy & 4 & 11.1 \\
\hline & Other cases & 20 & 55.6 \\
\hline
\end{tabular}


가 들어 갈 수 있게 원을 그리며 150회를 시행한 후 마무리하였다.

8) 각 단계마다 오른쪽도 동일하게 시행하였다.

\section{5. 자료 분석}

수집된 자료의 통계처리는 데이터코딩(data coding)과 데이터 클리닝(data cleaning)과정을 거쳐, Statistical Package for Social Science (SPSS V. 18.0; IBM, USA) 통계패키지 프로그램을 활용 하여 분석하였으며 스트레스, 피로, 우울의 차이를 살펴보기 위하 여 평균차이 검증인 t-test를 하였다.

\section{Results and Discussion}

\section{1. 응답자의 일반적 특성}

조사대상자의 일반적 특성은 연령대별로는 40대 18명(50.0\%), 50 대 18명(50.0\%)으로 나타났으며, 결혼 유무는 기혼 35명 (97.2\%), 사별 1명(2.8\%)으로 나타났다. 배우자가 있는 경우는 32 명(88.9\%)으로 나타났으며, 동거하는 가족은 자녀와 같이 산다 는 경우가 31 명(86.1\%), 혼자 사는 경우는 2 명(5.6\%)으로 나타 났다. 종교는 기독교 17명(47.2\%), 무교 9명(25.0\%), 불교 7명 (19.4\%), 천주교 3명(8.3\%)의 순서로 나타났으며, 학력은 고졸 23 명(63.9\%), 대졸 이상 11 명(30.6\%)으로 나타났으며, 월 소득 250만 원 이상이 29 명(80.6\%), 월 소득 150 만원 이하가 7명(19.4\%)으로 나타났다. 현재 받고 있는 치료는 물리치료 5명(13.9\%), 약물요법 및 자가 요법이 각각 4명(11.1\%)으로 나타났다(Table 1).

\section{2. 사전 동질성 검증 결과}

연구 변인인 피험자들의 스트레스, 피로, 우울 정도에 대한 실 험 전 사전 동질성 검증을 한 결과, 스트레스 평균 점수는 대조군의 경우 6.3점, 실험군의 경우 8.2점으로 나타났으며, 피로도는 대조 군의 경우 19.3 점, 실험군의 경우 19.3 점, 우울도는 대조군의 경우 5.8점, 실험군의 경우 6.8점으로 유의미한 차이가 없었다(Table 2). 혈압 및 맥박수의 동질성 검증 결과, 수축기 혈압은 대조군의 경우 $115.3 \mathrm{mmHg}$, 실험군의 경우 $110.4 \mathrm{mmHg}$, 이완기 혈압은 대조군 의 경우 $71.3 \mathrm{mmHg}$, 실험군의 경우 $64.5 \mathrm{mmHg}$ 로 나타났으며, 맥박의 경우는 대조군의 경우 74.2 회/min, 실험군의 경우 75.5 회/min로 나타나 유의미한 차이가 없었다(Table 3). 따라서 집단의 동질성은 확보되었음을 알 수 있다.

\section{3. 스트레스}

연구대상자의 스트레스 평균 점수는 대조군 7.2점, 실험군 4.1점 으로 소루상지마사지를 받은 실험군의 경우 대조군보다 낮은 스트 레스 점수로 나타났으며, $p<0.01$ 으로 두 집단간 유의미한 차이가 있었다(Table 4). 이는 소루상지마사지가 중년 직장여성 스트레스 를 감소시키는 효과가 있다는 것으로, 소루상지마사지가 중년 직장 여성의 스트레스 해소를 위한 여러 대체요법 방법 중 하나로 수행 하는 것이 바람직하다는 Jang (2000)의 연구와도 일치한 결과이다.

\section{4. 피로도}

연구대상자의 피로도 평균 점수는 대조군 19.5 점, 실험군 14.9 점으로 소루상지마사지를 받은 실험군의 경우 대조군보다 낮은 피 로도 점수를 보였으며, $p<0.01$ 으로 두 집단간 유의미한 차이가 있

Table 2. Verification of homogeneity about stress, fatigue, and depression before the experiment through the control and experimental groups

\begin{tabular}{|c|c|c|c|c|c|c|}
\hline & Division & $\mathrm{N}$ & Average & $\begin{array}{l}\text { Standard } \\
\text { deviation }\end{array}$ & $\mathrm{t}$ & $\begin{array}{c}\text { Significance probability } \\
\text { (both) }\end{array}$ \\
\hline \multirow{2}{*}{ Stress } & Control group & 20 & 6.3 & 3.74 & \multirow{2}{*}{-1.633} & \multirow{2}{*}{0.112} \\
\hline & Experimental group & 16 & 8.2 & 2.96 & & \\
\hline \multirow{2}{*}{ Fatigue } & Control group & 20 & 19.3 & 4.63 & \multirow{2}{*}{0.019} & \multirow{2}{*}{0.985} \\
\hline & Experimental group & 16 & 19.3 & 4.34 & & \\
\hline \multirow{2}{*}{ Depression } & Control group & 20 & 5.8 & 3.03 & \multirow{2}{*}{-0.988} & \multirow{2}{*}{0.330} \\
\hline & Experimental group & 16 & 6.8 & 2.86 & & \\
\hline
\end{tabular}

Table 3. Verification of blood pressure and pulse rate before the experiment through the control and experimental groups

\begin{tabular}{|c|c|c|c|c|c|c|}
\hline & Division & $\mathrm{N}$ & Average & $\begin{array}{l}\text { Standard } \\
\text { deviation }\end{array}$ & $\mathrm{t}$ & $\begin{array}{c}\text { Significance probability } \\
\text { (both) }\end{array}$ \\
\hline \multirow{2}{*}{$\begin{array}{l}\text { Systolic blood } \\
\text { pressure (mmHg) }\end{array}$} & Control group & 20 & 115.3 & 13.2 & \multirow{2}{*}{1.603} & \multirow{2}{*}{0.131} \\
\hline & Experimental group & 16 & 110.4 & 8.6 & & \\
\hline \multirow{2}{*}{$\begin{array}{l}\text { Diastolic blood } \\
\text { pressure (mmHg) }\end{array}$} & Control group & 20 & 71.3 & 9.7 & \multirow{2}{*}{1.404} & \multirow{2}{*}{0.102} \\
\hline & Experimental group & 16 & 64.5 & 7.0 & & \\
\hline \multirow{2}{*}{$\begin{array}{l}\text { Pulse rate } \\
\text { (/min) }\end{array}$} & Control group & 20 & 74.2 & 11.1 & \multirow{2}{*}{1.480} & \multirow{2}{*}{0.119} \\
\hline & Experimental group & 16 & 75.5 & 7.2 & & \\
\hline
\end{tabular}


었다(Table 5), 이와 같은 결과를 통해 소루상지마사지를 받은 중 년 직장여성이, 받지 않은 여성보다 피로도 점수가 낮을 것이라는 가설이 지지 되었는데 이는 Kim \& Suh (2004)의 연구와 동일하게 마사지 후 피로 상태가 유의미하게 좋아져 마사지의 피로 감소 효 과를 나타내는 것으로 볼 수 있다. 즉, 마사지는 대상자에게 관심을 집중하고 마사지 시 일어나는 유쾌한 신체적 감각을 통해 신뢰와 친밀한 인간관계를 조성함으로써 신체적 증상 경감과 아울러 심리 적 효과를 더욱 증진할 수 있어 신체적, 정신적, 영적 치유를 위한 돌봄을 제공하는 중재라 할 수 있다는 보고와 일치하는 것이다.

\section{5. 우울도}

연구대상자의 우울도 평균 점수는 소루상지마사지를 받은 실험 군의 경우 4.9 점, 대조군 6.0 점으로 나타나 실험군에서 낮게 나타났 으나 두 집단간 유의미한 차이가 없었다(Table 6). Field et al. (1992) 의 분만여성을 대상으로 한 연구에서 분만하는 동안 마사지를 한 집 단은 분만 후 우울이 낮았다고 보고하였는데, 본 연구에서는 우울 에 대하여 실험군과 대조군에서 유의미한 차이를 보이지 않았다.
이는 소루상지마사지의 경우 단기간의 효과를 기대하기보다는 좀 더 많은 시간적 여유를 두고 전후 상태를 측정하는 것이 바람직하 다는 것을 의미하는 것으로 사료된다.

\section{6. 혈압과 맥박수 변화}

연구대상자의 혈압 및 맥박수의 변화는 수축기 혈압의 경우 대 조군 $124.7 \mathrm{mmHg}$, 실험군 $109.0 \mathrm{mmHg}$ 로 나타났으며, 이완기 혈 압은 대조군 $81.4 \mathrm{mmHg}$, 실험군 $64.4 \mathrm{mmHg}$ 로 나타나 실험군의 수축기 혈압과 이완기 혈압이 낮게 나타났으며, 두 집단간 유의미 한 차이가 있었다( $p<0.001)$. 맥박수는 대조군이 75.8 회/min, 실험 군이 64.7 회 $/ \mathrm{min}$ 으로 나타나 실험군의 맥박수가 유의미하게 감소 하였다 $(p<0.001)$ (Table 7).

혈압 및 맥박은 스트레스 상승 시의 생리적 지표로서 많이 활용 되는데 스트레스로 인해 자율신경계의 교감신경계가 흥분하면 부 신수질과 말초신경에서 노르에피네프린(norepinephrine)과 에피 네프린(epinephrine)이 분비되어 혈관을 수축시켜 혈압을 상승시 킨다(Choe et al., 1991). 결국 교감신경의 활성화에 기인하여 반복

Table 4. Alteration of the stress score after the Sorusangzi massage

\begin{tabular}{lccccc}
\hline \multicolumn{1}{c}{ Division } & $\mathrm{N}$ & Average & $\begin{array}{c}\text { Standard } \\
\text { deviation }\end{array}$ & $\mathrm{t}$ & $\begin{array}{c}\text { Significance probability } \\
\text { (both) }\end{array}$ \\
Control group & 20 & 7.2 & 3.45 & \multirow{2}{*}{3.248} & $0.003^{* *}$ \\
Experimental group & 16 & 4.1 & 1.77 & & \\
\hline
\end{tabular}

${ }^{* *} p<0.01$

Table 5. Alteration of the fatigue score after the Sorusangzi massage

\begin{tabular}{lccccc}
\hline \multicolumn{1}{c}{ Division } & $\mathrm{N}$ & Average & $\begin{array}{c}\text { Standard } \\
\text { deviation }\end{array}$ & $\mathrm{t}$ & $\begin{array}{c}\text { Significance probability } \\
\text { (both) }\end{array}$ \\
Control group & 20 & 19.5 & 4.81 & 3.404 & $0.002^{* *}$ \\
Experimental group & 16 & 14.9 & 2.69 & & \\
\hline${ }^{* *} p<0.01$. & & &
\end{tabular}

Table 6. Alteration of the depression score after the Sorusangzi massage

\begin{tabular}{|c|c|c|c|c|c|}
\hline Division & $\mathrm{N}$ & Average & $\begin{array}{l}\text { Standard } \\
\text { deviation }\end{array}$ & $\mathrm{t}$ & $\begin{array}{c}\text { Significance probability } \\
\text { (both) }\end{array}$ \\
\hline Control group & 20 & 6.0 & 3.02 & \multirow{2}{*}{1.036} & \multirow{2}{*}{0.308} \\
\hline Experimental group & 16 & 4.9 & 3.27 & & \\
\hline
\end{tabular}

Table 7. Alteration of the blood pressure and pulse rate after the Sorusangzi massage

\begin{tabular}{|c|c|c|c|c|c|c|}
\hline \multicolumn{2}{|c|}{ Division } & \multirow{2}{*}{$\begin{array}{l}N \\
20\end{array}$} & \multirow{2}{*}{$\begin{array}{c}\text { Average } \\
124.7\end{array}$} & \multirow{2}{*}{$\begin{array}{c}\text { Standard } \\
\text { deviation } \\
10.1\end{array}$} & \multirow{3}{*}{$\begin{array}{c}\mathrm{t} \\
4.228\end{array}$} & \multirow{3}{*}{$\begin{array}{c}\text { Significance probability } \\
\text { (both) } \\
0.000^{* * *}\end{array}$} \\
\hline \multirow{2}{*}{$\begin{array}{l}\text { Systolic blood pressure } \\
(\mathrm{mmHg})\end{array}$} & Control group & & & & & \\
\hline & Experimental group & 16 & 109.0 & 10.1 & & \\
\hline \multirow{2}{*}{$\begin{array}{l}\text { Diastolic blood pressure } \\
(\mathrm{mmHg})\end{array}$} & Control group & 20 & 81.4 & 8.2 & \multirow{2}{*}{5.793} & \multirow{2}{*}{$0.000^{* * *}$} \\
\hline & Experimental group & 16 & 64.4 & 8.3 & & \\
\hline \multirow{2}{*}{$\begin{array}{l}\text { Pulse rate } \\
\text { (/min) }\end{array}$} & Control group & 20 & 75.8 & 8.5 & \multirow{2}{*}{4.397} & \multirow{2}{*}{$0.000^{* * *}$} \\
\hline & Experimental group & 16 & 64.7 & 3.6 & & \\
\hline
\end{tabular}


적인 스트레스가 혈압의 상승을 이끌고 이는 건강을 크게 손상시킬 수 있음을 보여주는 것으로 실제 혈압의 상승과 관련된 건강상의 위험은 115/75 mmHg에서 시작된다(Pickering et al., 2005).

마사지는 보완대체요법 중에서 가장 효과적이고 널리 사용되는 방법으로(Field et al., 2007), 오랫동안 인간의 질환을 치료하기 위 한 수단으로 사용되어왔다(Theil, 1975). 또한 마사지를 통하여 인 간의 신체적 - 심리적 증상이 조절되고 건강이 증진되기 때문에 임 상에서 다양한 방면으로 활용 가능하다(Roh et al., 2009). 본 연구 에서는 소루상지마사지를 받은 중년 직장여성들의 혈압과 맥박수 가 유의하게 감소한 것으로 나타나 마사지가 스트레스를 감소시켜 혈압과 맥박의 감소 효과를 나타낸다는 것을 입증하였다.

\section{$\overline{\text { Conclusion }}$}

본 연구는 소루상지마사지가 중년 직장여성의 스트레스, 피로, 우울, 혈압, 맥박에 미치는 영향을 규명하고자 진행하였다. 소루 상지마사지 후 스트레스 차이를 살펴보면 대조군은 7.2점, 실험군 은 4.1점으로 나타나 실험군이 대조군보다 낮은 스트레스를 보였 으며 $(p<0.01)$, 피로의 차이를 살펴보면 대조군은 19.5 점, 실험군 은 14.9 점으로 나타나 실험군이 대조군보다 낮은 피로도를 보였다 $(p<0.01)$. 우울의 경우, 대조군은 6.0점, 실험군은 4.9점으로 나타 나 실험군은 대조군보다 낮은 우울도를 보이는 것을 알 수 있으나 유의미한 차이를 보이지는 않았다.

혈압의 경우 대조군의 수축기 혈압은 평균 $124.7 \mathrm{mmHg}$, 이완기 혈압은 평균 $81.4 \mathrm{mmHg}$ 이었으나 실험군의 수축기 혈압은 109.0 $\mathrm{mmHg}$, 이완기 혈압은 $64.4 \mathrm{mmHg}$ 으로 실험군의 혈압이 낮게 나 타났으며 $(p<0.001)$, 맥박수는 대조군 75.8 회 $/ \mathrm{min}$, 실험군 64.7 회/min으로 실험군에서 유의적으로 감소했다( $p<0.001)$. 이러한 결 과는 소루상지마사지는 스트레스 해소와 피로회복에 효과가 있어 스트레스와 피로, 우울을 경험하는 중년 직장여성들의 심리적 안정 과 삶의 질 향상에 도움을 줄 뿐만 아니라 피로와 스트레스를 감소 시켜 건강한 고령화 사회를 맞이할 수 있도록 하는데 중요한 중재 적 대체요법이 될 수 있을 것으로 판단되었다.

\section{References}

Cho HJ, Cho SJ. A study of application of alternative medicine to the care of the aged with chronic diseases: focusing on the nursing homes for the aged. Intentional Journal of Complementary, Integrative and Alternative Medicine, 3: 179-193, 2007.

Choe MA, Hwang AR, Kim HS. Clinical physiology in nursing.
Korean Nurses Association, Seoul, pp42-55, 1991.

Ernst E. Massage treatment for back pain. British Medical Journal, 326: 562-563, 2003.

Field T, Diego M, Hernandez-Reif M. Massage therapy research. Developmental Review, 27: 75-89, 2007.

Field T, Morrow C, Valdeon C, Larson S, Kuhn C, Schanberg $\mathrm{S}$. Massage reduces anxiety in child and adolescent psychiatric patients. Journal of the American Academy of Child and Adolescent Psychiatry, 31: 125-131, 1992.

Haber JD, Kuczmierczyk AR, Adams HE. Tension headaches: muscle overactivity or psychogenic pain. Headache, 25 : 23-29, 1985.

Han CY, Shin JH, Lee MJ. The effect of Soru massage therapy on pain of the head and neck of elderly. The Journal of the Korea Institute of Electronic Communication Sciences, 8: 1265-1270, 2013.

Han YJ, Kang KS. Effects of a Qi massage program on the physio-psychological state of industrial employees with hypertension. Journal of East-West Nursing Research, 20: 73-80, 2014.

Heo JS, Lee HJ, Jeong $\mathrm{CH}$. A study on types of portal sites preferences among the Korea elderly. The Journal of the Korea Institute of Electronic Communication Sciences, 8: 713-724, 2013.

Jang $\mathrm{HJ}$. The psychological effect of hand and arm massage on middle-aged women. Journal of Korean Academy of Nursing, 30: 1389-1399, 2000.

Kim EG, Lee DM, Lee JB, Park HS. Prevalence of atherosclerotic risk factors. Korean Journal of Family Medicine, 15: 622-631, 1994.

Kim HY. A study of women's employment trajectories in middle ages. Korean Social Security Studies, 26: 233259, 2010.

Kim NJ, Suh I. The relationship between exercise and perceived stress in employees. Korean Journal of Health Education and Promotion, 21: 101-115, 2004.

KOSIS (Statistics Korea, 2015 Older statistics), 2015.09.24.

Kwon E, Nah EH, Kim H, Joe SH, Cho HI. Association between metabolic syndrome and psychological characteristics in Korean postmenopausal women. Korean Journal of Health Promotion, 16: 119-126, 2016.

Lee YH, Song JY. A study of the reliability and the validity of the BDI, SDS, and MMPI-D scales. Korean Journal of Clinical Psychology, 10: 98-113, 1991. 
Park BY, Ko DS, Park HS. Relationship between job characteristic and quality of life among some elderly. The Journal of the Korea Institute of Electronic Communication Sciences, 8: 941-947, 2013.

Park GJ, Lee KH. A structural model for depression in middleaged women. Korean Journal of Women Health Nursing, 8: 69-84, 2002.

Park MS, Suh MJ. The effect of the hand massage on anxiety of the cancer patients receiving radiation treatment. Journal of Korean Academy of Nursing, 25: 316-329, 1995.

Pickering TG, Hall JE, Appel LJ, Falkner BE, Graves J, Hill MN, Jones DW, Kurtz T, Sheps SG, Roccella EJ. Recommendations for blood pressure measurement in humans and experimental animals. Hypertension, 45: 142-161, 2005.
Roh YS, Kim SS, Kim Jl. The analysis of research on massage interventions for patients in Korea. Journal of Korean Clinical Nursing Research, 15: 171-182, 2009.

Shim JM. The effect of manual lymphatic drainage on the change of eletrocardiogram. Asian Journal of Beauty and Cosmetology, 4: 211-223, 2006.

Theil P. Massage therapy in classical Chinese physical medicine. The American Journal of Chinese Medicine, 3: 83-85, 1975. 


\section{국문초록}

\section{소루상지마사지가 직장여성의 스트레스, 피로, 우울에 미치는 영향}

박지온, 손연희, 주은화

조선대학교 보완대체의학과, 광주, 한국

목적: 본 연구는 소루상지마사지가 중년 직장여성들이 갖고 있는 스트레스, 만성피로 및 우울에 대처하는데 도움을 줄 수 있는지를 연 구하여 건강한 고령사회를 맞이하는데 중재적 대체요법으로의 활용 가능성을 확인하고자 하였다. 방법: 본 연구는 보험설계사로 활 동하고 있는 중년 직장여성을 대상으로 하여 실험군과 대조군으로 20 명씩 나누어 실험군은 6 주에 걸쳐 주 2 회 소루상지마사지를 시행 한 후 스트레스 정도, 피로도, 우울도, 혈압 및 맥박수를 측정하였다. 결과: 소루상지마사지 후 스트레스 평균 점수는 대조군 7.2점, 실 험군 4.1점으로, 피로도 평균 점수는 대조군의 경우에 19.5 점, 실험군 14.9 점으로 실험군의 경우에 대조군보다 낮게 나타났다. 우울도 의 경우, 대조군은 6.0 점, 실험군은 4.9 점으로 나타나 실험군의 경우에 대조군보다 낮은 우울도를 보이는 것을 알 수 있었다. 혈압 및 맥박수 변화는 수축기 혈압은 대조군이 $124.7 \mathrm{mmHg}$, 실험군이 $109.0 \mathrm{mmHg}$ 이고, 이완기 혈압은 대조군 $81.4 \mathrm{mmHg}$, 실험군 64.4 $\mathrm{mmHg}$ 으로 실험군의 혈압이 낮게 나타났다. 맥박수는 대조군이 75.8 회 $/ \mathrm{min}$, 실험군 64.7 회/min으로 실험군의 맥박수가 감소했다. 결론: 소루상지마사지가 중년 직장여성들의 스트레스 및 피로 해소에 도움을 주어 심리적 안정과 삶의 질을 향상시킬 수 있으며, 이를 통해 건강한 고령화 사회를 맞이하는데 중요한 중재적 대체요법이 될 수 있을 것으로 사료된다.

핵심어: 소루상지마사지, 스트레스, 피로, 우울, 중년여성

\section{참고문헌}

김남진, 서일. 직장인들의 운동실천 정도와 스트레스의 관련성. 보건교육건강증진학회지, 21: 101-115, 2004.

김혜연. 중 · 장년 여성의 노동시장 참여경로 유형화에 관한 연구. 사회보장연구, 26: 233-259, 2010.

노영숙, 김소선, 김종일. 환자를 대상으로 마사지 중재를 적용한 국내 연구 분석. 임상간호연구, 15: 171-182, 2009.

박금자, 이경혜. 중년여성의 우울 구조모형. 여성건강간호학회지, 8: 69-84, 2002.

박부연, 고대식, 박형수. 노인의 직업특성과 삶의 질과의 관련성. 한국전자통신학회 논문지, 8: 941-947, 2013.

심정묘. 엠엘디(MLD)가 심전도에 미치는 영향. 아시안뷰티화장품학술지, 4: 211-223, 2006.

조현준, 조성준. 노인 만성질환자 케어를 위한 대체의학 적용에 관한 연구: 노인요양시설을 중심으로. 국제통합보완대체의학

회지, 3: 179-193, 2007.

최명애, 황애란, 김희승. 간호 임상 생리학. 대한간호협회 출판부, 서울, pp42-55, 1991.

한윤주, 강경숙. 기마사지요법이 고혈압 환자의 생리 - 심리적 상태에 미치는 효과. 동서간호학연구지, 20: 73-80, 2014.

한채연, 신지훈, 이미자. 소루마사지요법이 노인의 두경부 통증에 미치는 영향. 한국전자통신학회 논문지, 8: 1265-1270,

2013.

허준선, 이홍직, 정찬희. 노인의 포털사이트 선호 유형에 관한 연구. 한국전자통신학회 논문지, 8: 713-724, 2013.

KOSIS (통계청, 2015 고령자 통계), 2015.09.24. 


\section{中文摘要}

\section{Sorusangzi按摩对职业女性的压力、疲劳、忧郁的影响}

朴持穩 ${ }^{*}$, 孫連嬉, 朱銀花

朝鮮大學補完代替醫學科, 光州, 韩国

目的: 探讨Sorusangzi按摩对中年职业女性的压力、慢性疲劳、忧郁的影响, 判断Sorusangzi按摩是否能成为在进入健康老 龄化社会的阶段中作为代替疗法的可行性。方法: 职业为保险设计师的中年女性为研究对象, 被分为实验组和对照组, 每组 包括20名参与者。实验组每周进行两次Sorusangzi按摩之后, 测定压力程度、疲劳度、忧郁度、血压以及脉搏数, 实验周 期为共6周。结果: Sorusangzi按摩之后, 压力平均分结果显示, 对照组为 7.2 分, 实验组为4.1分; 疲劳度平均分结果显示, 对照组为 19.5 分, 实验组为 14.9 分; 忧郁度平均分结果显示, 对照组为 6.0 分, 实验组为 4.9 分。从中可确认实验组的压力, 疲劳度以及忧郁度都明显低于对照组。关于血压及脉搏率的变化，收缩压的结果显示，对照组为 $124.7 \mathrm{mmHg}$ ，实验组为 $109.0 \mathrm{mmHg}$; 舒张压结果显示, 对照组为 $81.4 \mathrm{mmHg}$, 实验组为 $64.4 \mathrm{mmHg}$, 从中可以确认实验组的血压明显低于对照 组。脉搏率结果显示, 对照组为 75.8 次 $/ \mathrm{min}$, 实验组为 64.7 次 $/ \mathrm{min}$, 实验组的脉搏率明显降低。结论: 通过研究结果表明, Sorusangzi按摩能缓解中年职业女性的压力和疲劳, 从而改善中年女性的心理压力和生活质量, 因此在进入健康的老龄化社 会作为代替疗法充分具有可行性。

关键词: Sorusangzi按摩, 压力, 疲劳, 忧郁, 中年女性 